\title{
ANALIZA POLIMORFIZMA RS185042 U GENU ZA KARBOANHIDRAZU VII KOD DECE SA IDIOPATSKIM FEBRILNIM KONVULZIJAMA
}

\author{
Branislava Ćosić ${ }^{1}$, Milan Stojković ${ }^{1}$, Marko Svetel ${ }^{1}$, Dijana Perović ${ }^{2}$ \\ ${ }^{1}$ Medicinski fakultet Univerziteta u Beogradu \\ ${ }^{2}$ Mentor; Institut za humanu genetiku, Medicinski fakultet Univerziteta u Beogradu
}

Sažetak

Zaključak: Dobijeni rezultati ukazuju na statistički značajnu razliku u distribuciji alela na lokusu rs185042 CAVII gena između dece obolele od FK i kontrolne grupe, ali se samo na osnovu toga ne može pouzdano tvrditi da je sam gen od ključnog značaja u etiologiji febrilnih konvulzija.

Uvod: Febrilne konvulzije (FK) su najčešće konvulzije dečjeg doba. Javljaju se sa učestalošću od 2-5\%. Uočeno je da se u nekim porodicama FK javljaju češće, što je ukazalo na genetsku predispoziciju. U poslednje vreme se sve više ispituju različiti enzimi, čija katalitička aktivnost utiče na dinamiku $\mathrm{pH}$ i posledično na ekscitabilnost neurona, među kojima je i enzim karboanhidraza VII (CAVII). Alkalna sredina indukuje povećanje ekscitabilnosti koja je često dovoljno intenzivna za pokretanje epileptiformnih aktivnosti.

Cilj: Cilj ovog rada bio je da se ispita da li postoji razlika u učestalosti genotipa na lokusu rs185042 CAVII gena između dece obolele od FK i kontrolne grupe.

Materijal i metode: U ovo istraživanje uključeno je 32 dece sa dijagnostikovanim febrilnim konvulzijama i 226 zdrave dece koja su činila kontrolnu grupu. CAVII polimorfizam rs185042 analiziran je metodom PCR/ RFLPs (polymerase chain reaction/restriction fragments length polymorphism).

Rezultati: Utvrđeno je da postoji statistički značajna razlika u učestalosti genotipova i alela na lokusu rs185042 gena CAVII između dece sa FK i zdravih kontrola.

Ključne reči: Febrilne konvulzije, CAVII gen, polimorfizam rs185042.

\section{Abstract}

Conclusion: The results indicate statistically significant difference in the distribution of alleles at the locus rs185042 of the CAVII gene between children with febrile seizures and control group, however, based on this indication only, it cannot be reliably confirmed that CAVII gene alone is a key determinant in the development of febrile seizures.

Introduction: Febrile seizures (FS) are the most common seizures during childhood age. The frequency of their occurance is in the range of $2-5 \%$. It was observed that some families have higher incidence of FS, which indicated a genetic predisposition. Various enzymes, including carbonic anhydrase VII (CAVII), have been under progressive examination lately due to their influence on dynamics of $\mathrm{pH}$ shifts and consequently on neuronal functions. The increase in excitability is induced by alkaline shifts and is often intense enough to trigger epileptiform activity.

The Aim: The main purpose of this study was to establish whether there is a difference in frequency of genotype between the CAVII gene locus rs 185042 in children diagnosed with FS and in control group.

Material and methods: This research included 32 children diagnosed with febrile seizures and 226 healthy children in the control group. The CAVII rs185042 polymorphism was analysed by PCR/RFLPs (polymerase chain reaction/restriction fragments length polymorphism).

Results: It was established that statistically significant difference in the incidence of genotypes and alleles on the CAVII gene locus rs185042 exists in children diagnosed with FS than in healthy control group.

Key words: Febrile seizures, CAVII gene, polymorphism rs185042. 


\section{Uvod}

Febrilne konvulzije (FK) su napadi generalizovanih toničko-kloničkih grčeva izazvani povišenom telesnom temperaturom (iznad $38,5^{\circ} \mathrm{C}$ ) u toku infekcije koja primarno ne zahvata centralni nervni sistem. Tipično se javljaju kod dece između 6 meseci i 6 godina starosti [1], a osim tipičnih, postoje i atipične koje se odlikuju drugačijom kliničkom slikom: javljaju se i pre šestog meseca i posle šeste godine života, mogu se ponoviti u toku iste febrilne epizode, javljaju se i kod temperatura nižih od $38,5^{\circ} \mathrm{C}$ i traju duže od pola sata. Statistički podaci pokazuju da FK ima 2-5 \% dece [2]. Febrilne konvulzije imaju tendenciju da se pojavljuju familijarno, što ukazuje na to da postoji genetska predispozicija [3,4]. Verovatnoća pojave febrilnih napada kod dece čiji je srodnik prvog stepena imao napade je $10 \%$, dok se ta verovatnoća povećava do $50 \%$ ukoliko su i roditelji imali slične neurološke probleme [5]. Važnost uloge nasledne osnove ali i sličnog spoljnjeg okruženja u ispoljavanju FK prikazana je kroz studije sa blizancima u kojima je pokazano da oba deteta iz blizanačkog para ima bar jednu epizodu FK kod 35\% jednojajčanih odnosno $15 \%$ dvojajčanih blizanaca [6]. Tokom proteklih nekoliko decenija otkriveni su brojni genski lokusi povezani sa FK, koji ukazuju na izuzetnu poligensku kompleksnost ovog poremećaja [7]. Na ovim lokusima nalaze se geni za različite jonske kanale, i to na hromozomima 8 (8q13-q21 - FEB1), 19 (19p - FEB2), 2 (2q23-q24 - FEB3), 5 (5q14-q15 - FEB4, 5q34 - FEB8), 6 (6q22-q24 - FEB5), 18 (18p11 - FEB6), 21 (21q22 FEB7) i 3 (3p23-p24 - FEB9, 3q26 - FEB10).

Karboanhidraza (CA) je enzim koji učestvuje, pored ostalog, i u regulaciji acido-bazne ravnoteže. Karboanhidraza katališe reverzibilnu reakciju između ugljen-dioksida i vode pri čemu nastaje slaba ugljovodonična kiselina. Kod sisara postoji 7 izoformi ovog enzima sa različitom tkivnom distribucijom [8]. Poznato je da CA u mozgu moduliše nervnu signalizaciju tako što utiče na amplitudu i kinetiku promena $\mathrm{pH}$ i posledično na funkciju brojnih proton-senzitivnih membranskih proteina koji učestvuju u nervnoj signalizaciji kao što su GABAAR $[9,10]$, NMDAR $[11,12]$, jonski kanali aktivirani niskim $\mathrm{pH}$ [13], katjonski kanali [14, 15] i porozne veze (gap-junctions) [16].

Novija istraživanja na miševima upućuju na važnu ulogu karboanhidraze VII (CAVII) [17]. Ovaj izoenzim je uglavnom eksprimiran u mozgu, a kodiran CAVII genom, koji se $u$ humanom genomu nalazi na dugom kraku hromozoma 16, u regionu 16q21-23 [18]. Pokazano je da CAVII olakšava nastanak FK, paradoksalno, povećanjem GABA-ergičke aktivnosti [19]. Naime, intraneuralna aktivnost CA odgovorna je za brzo stvaranje $\mathrm{HCO}_{3}^{-}$, čiji neto efluks dovodi do GABA-ergičke depo- larizacije i posledičnog olakšanog neto preuzimanja i akumulacije $\mathrm{Cl}^{\text {, }}$ što je ključni mehanizam za generisanje ekscitatonog od $\mathrm{HCO}_{3}^{-}$zavisnog GABA-ergičkog odgovora $[20,21]$. CAVII ima jedinstvenu ulogu da olakša akumulaciju Cl- [21].

Polimorfni lokus rs185042 nalazi se u trećem intronu gena CAVII. Ova supstitucija G > A ima moguću regulatornu ulogu i do sada je proučavana u malom broju neuroloških poremećaja.

Cilj ovog istraživanja je da se utvrdi distribucija genotipa i razlika u učestalosti alela $\mathrm{G}$ i A polimorfizma rs185042 između pacijenata sa febrilnim konvulzijama i ispitanika kontrolne grupe.

\section{Materijal i metode}

\section{Ispitanici}

Ispitivanjem je obuhvaćeno 38 obolele dece sa dijagnostikovanim febrilnim konvulzijama. Pacijenti potiču iz različitih porodica i detaljno su klinički obrađeni na Univerzitetskoj dečjoj klinici u Beogradu. Kontrolnu grupu činilo je 226 dece iz opšte populacije koja nisu imala febrilne konvulzije.

Molekularno-genetičko ispitivanje je obavljeno u laboratoriji Instituta za humanu genetiku Medicinskog fakulteta Univerziteta u Beogradu. Studija je izvedena u skladu sa etičkim standardima i pravilima Etičkog komiteta KCS.

\section{Molekularno-genetička analiza}

Izolacija genomske DNK je vršena iz uzoraka periferne venske krvi metodom isoljavanja. Određivanje genotipa na lokusu rs 185042 gena CAVII vršeno je PCR/ RFLPs (polymerase chain reaction/ restriction fragments length polymorphism) metodom. U prvoj fazi je u PCR reakciji amplifikovan segment gena CAVII koji sadrži lokus rs185042, a zatim je vršena digestija PCR produkta restrikcionim enzimom DraIII. Ovaj enzim prepoznaje sekvencu CACNNN/GTG i seče PCR produkt u slučaju postojanja alela $\mathrm{G}$ na analiziranom lokusu, dok u slučaju postojanja alela A ne dolazi do isecanja.

U PCR reakciji korišćeni su prajmeri čija je sekvenca: Fw: 5'-GTGCATGGCCCCAGCTCACTG-3' i Rv: 5'-AGTGCCGCCTCCCCCAGAAAT-3'. Smeša za PCR reakciju je imala zapreminu $25 \mathrm{mcl}$, i sledeći sastav: 2,5 mcl10x PCR pufer (sa $\mathrm{MgCl}_{2}$ ), 1,5 mcl dNTPs (10 $\mathrm{mM}$ svaki), 0,5 mcl od svakog prajmera Fw i Rv (300 ng/ $\mathrm{mcl}), 0,2 \mathrm{mcl}$ Taq polimeraza (Sigma), $2 \mathrm{mcl}$ DNK (100 $\mathrm{ng} / \mathrm{mcl}$ ), do $25 \mathrm{mcl} \mathrm{H} 2 \mathrm{O}$.

Uslovi PCR reakcije su bili: početna denaturacija $950 \mathrm{C} / 10 \mathrm{~min}, 40$ ciklusa (koraci 2-4): denaturacija 940 C $45 \mathrm{~s}$, hibridizacija prajmera $650 \mathrm{C} 45 \mathrm{~s}$, elongacija 720 C 45 s, završna elongacija 720 C 7 min, 40 C za čuvanje 
uzorakaVeličina PCR produkta iznosi 98bp.

Reakciona smeša za digestiju restrikcionim enzimom je imala sastav: PCR produkt $7 \mathrm{mcl}$, Dra III enzim (Thermo Scientific) 5U, 10x pufer G 2 mcl, vode do 15 mcl. Uzorci su inkubirani na $370 \mathrm{C}$ preko noći, a potom je vršena gel elektroforeza produkata digestije na $8 \%$ PAA gelu. Restrikcioni fragmenti su analizirani nakon bojenja gelova bojom SybrSafe i prosvetljavanja na UV trans-iluminatoru.

DraIII seče PCR produkt na poziciji G alela lokusa rs185042, a dobijeni restrikcioni fragmenti su veličine 83bp i 15bp. Tako uzorak genotipa AA ima samo jednu traku veličine 98bp, uzorak genotipa AG ima trake od 98bp, 83bp i 15bp, dok uzorak genotipa GG ima trake veličine $83 \mathrm{bp}$ i $15 \mathrm{bp}$.

\section{Statistička analiza}

Statistička analiza dobijenih rezultata vršena je $\chi 2$ testom korišćenjem GraphPad kompjuterskog programa. Kao kriterijum značajnosti uzete su $\mathrm{p}<0,05$ (statistički značajno) i p $<0,01$ (statistički visoko značajno).

\section{Rezultati}

Najučestaliji genotip u obe ispitivane grupe bio je AG, koji je prisutan kod 56,25\% ispitanika sa FK i 47,8\% ispitanika u kontrolnoj grupi (KG). Genotip GG nađen je kod $18,75 \%$ dece sa FK i $33,6 \%$ dece iz kontrolne grupe, dok genotip AA ima 25\% dece sa FK i 18,6\% kontrolne grupe (grafikoni 1 i 2). Na osnovu uočene frekvence genotipova određena je učestalost alela A i G u ispitivanim grupama (tabela 1). Međusobnim poređenjem $\chi 2$ testom utvrđeno da postoji statistički značajna razlika u distribuciji alela između ovih grupa, tj. da je alel A značajno češći kod dece sa FK u odnosu na kontrolnu grupu $(\mathrm{p}=0,043)$.

To je potvrđeno poređenjem učestalosti genotipova, pri čemu su jednu kategoriju činili nosioci A alela (genotipovi $A A+A G$ ), a drugu kategoriju ispitanici bez $A$ alela (genotip GG). Testiranje $\chi^{2}$ testom pokazalo je visoko statistički značajnu razliku između bolesnika sa FK $\mathrm{i}$ kontrolne grupe $(\mathrm{p}=0.0029)$.

Tabela 1. Učestalost alelnih kopija na lokusu rs185042.

\begin{tabular}{|l|l|l|}
\hline Ispitanici & G & A \\
\hline FK & $30 / 64(46,87 \%)$ & $34 / 64(53,13 \%)$ \\
\hline KG & $260 / 452(57,52 \%)$ & $192 / 452(42,48 \%)$ \\
\hline
\end{tabular}

\section{Diskusija}

CAVII je pretežno eksprimiran u neuronima. Prema Ruusuvuori i sar. [17] ova izoforma povećava bikarbonatima izazvanu GABA-ergičku ekscitaciju tokom intenzivne aktivacije GABAA receptora. Smatra se da učestvuje u modulaciji sinaptičke transmisije u brojnim strukturama CNS-a koje uključuju korteks, hipokampus i bazalne ganglije, gde dovodi do hiperekscitabilnosti, što je polazna pretpostavka o njegovoj ulozi u nastanku

Grafikon 1. Grafički prikaz procentualne učestalosti pojedinačnih genotipova na lokusu rs185042 kod ispitanika sa febrilnim konvulzijama.

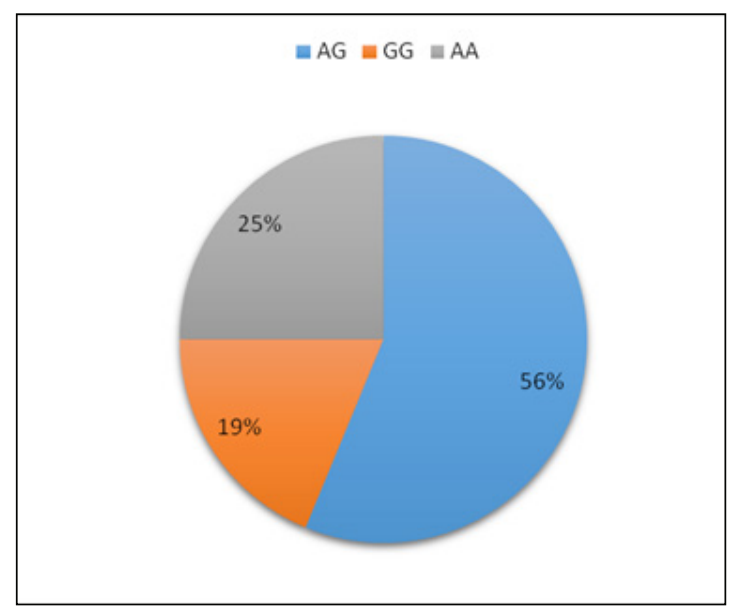

Grafikon 2. Grafički prikaz procentualne učestalosti pojedinačnih genotipova na lokusu rs 1805042 kod ispitanika kontrolne grupe

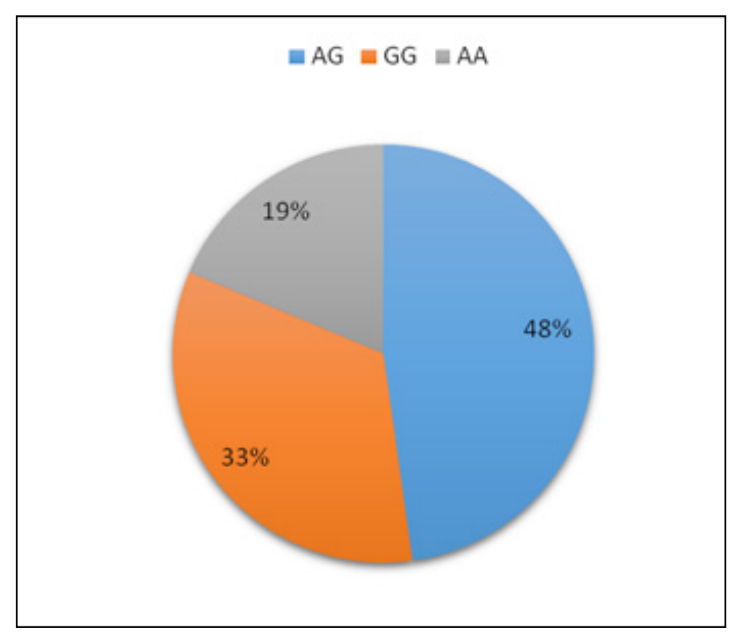

FK. Iako do sada nisu publikovane genetske studije koje direktno povezuju CAVII i FK u humanoj populaciji, laboratorijski eksperimenti na sojevima miševa (knockout mouse, $K O$ ), kojima je potpuno izbačen iz funkcije ovaj gen, pokazala su da je bez njega GABA evocirana depolarizacija znatno manja. Po izlaganju visokim tempera- 
turama na EEG-u nije zapažena nikakva epileptiformna aktivnost u 100\% ispitivanih KO [17].

U našem istraživanju utvrdili smo da je A alel polimorfnog lokusa rs185042 u okviru CAVII gena mogući faktor podložnosti za FK. U radu smo se bavili analizom udruženosti samo jednog polimorfnog lokusa CAVII gena i pojave FK, što je možda glavni razlog za oprez pri donošenju definitivnog zaključka $s$ obzirom na to da je u molekularno-genetskim studijama identifikovano mnoštvo genetskih faktora uključenih u razvoj ovog poremećaja [1].

$\mathrm{Na}$ osnovu rezultata ovog istraživanja može se zaključiti da CAVII gen ima određenu ulogu u nastanku febrilnih konvulzija, ali su neophodna dalja ispitivanja da bi se objasnio značaj polimorfnog lokusa rs185042 u etiologiji ovog poremećaja. Osim toga, a s obzirom na genetsku složenost ove bolesti, bilo bi potrebno da se analizira veći broj gena i njihov međusobni uticaj na nastanak ove bolesti.

\section{Literatura}

1. Nakayama J. Progress in searching for the febrile seizure susceptibility genes. Brain \& Development. 2009; 31: 359365.

2. Verity CM, Butler NR, Golding J. Febrile convulsions in a national cohort followed up from birth. I-Prevalence and recurrence in the first five years of life. British Medical Journal (Clin Res Ed). 1985; 290; 6478: 1307-1310.

3. Nelson KB, Ellenberg JH. Prenatal and perinatal antecedents of febrile seizures. Annals of Neurology. 1990; 27;2: 127-131.

4. Berg AT, Shinnar S, Shapiro ED, Salomon ME, Crain EF, Hauser WA. Risk factors for a first febrile seizure: a matched case-control study. Epilepsia. 1995; 36;4: 334341.

5. Bogićević D. Febrilni napadi. Medicinski podmladak. 2012; 63;1-2: 36-40

6. Corey LA, Berg K, Pellock JM, Solaas MH, Nance WE, DeLorenzo RJ. The occurrence of epilepsy and febrile seizures in Virginian and Norwegian twins. Neurology. 1991; 41; 9: 1433-1436.

7. Piro RM, Molineris I, Ala U, Di Cunto F. Evaluation of Candidate Genes from Orphan FEB and GEFS + Lociby Analysis of Human Brain Gene Expression Atlases. PLoS ONE. 2011; 6;8: e23149. doi:10.1371/journal. pone.0023149.

8. Lindskog S. Structure and mechanism of carbonic anhydrase. Pharmacol Ther. 1997; 74; 1: 1-20.

9. Pasternack M, Smirnov S, Kaila K. Proton modulation of functionally distinct GABAA receptors in acutely isolated pyramidal neurons of rat hippocampus. Neuropharmacology. 1996; 35; 9-10: 1279-1288.

10. Wilkins ME, Hosie AM, Smart TG. Proton modulation of recombinant GABAA receptors: influence of GABA con- centration and the â subunit TM2-TM3 domain. J Physiol. 2005; 567; 2: 365-377.

11. Traynelis SF, Wollmuth LP, et al. Glutamate Receptor Ion Channels: Structure, Regulation, and Function. Pharmacological Reviews. 2010; 62; 3: 405-496.

12. Makani S, Chen HY, et al. Receptor-Dependent Afterdepolarizations Are Curtailed by Carbonic Anhydrase 14: Regulation of a Short-Term Postsynaptic Potentiation. The Journal of Neuroscience. 2013; 32; 47: 16754-16762.

13. Waldmann R Champigny G, Bassilana F, Heurteaux C. Lazdunski M. A proton-gated cation channel involved in acid-sensing. Nature. 1997; 386; 6621: 173-177.

14. Williams RH, Jensen LT, Verkhratsky A, Fugger L, Burdakov D. Control of hypothalamic orexin neurons by acid and CO2. Proc Natl Acad Sci USA. 2007; 104; 25: 10685 10690.

15. Enyedi P, CzirjákG. Molecular background of leak K+ currents: two-pore domain potassium channels. Physiol Rev. 2010; 90; 2: 559-605.

16. Spray DC, Harris AL, Bennett MV. Gap junctional conductance is a simple and sensitive function of intracellular pH. Science. 1981; 211; 4483: 712-715.

17. Ruusuvuori E, Huebner AK, et al. Neuronal carbonic anhydrase VII provides GABAergic excitatory drive to exacerbate febrile seizures. Embo j. 2013; 32; 16: 2275-2286.

18. Montgomery JC, Venta PJ, Eddy RL, Fukushima YS, Shows TB, Tashian RE. Characterization of the human gene for a newly discovered carbonic anhydrase, CA VII, and its localization to chromosome 16. Genomics. 1991; 11; 4: 835-848.

19. Alger BE, Nicoll RA. Pharmacological evidence for two kinds of GABA receptor on rat hippocampal pyramidal cells studied in vitro. J Physiol. 1982; 328: 125-141.

20. Ruusuvuori E, Li H, Huttu K, Palva JM, Smirnov S, Rivera C, Kaila K, Voipio J. Carbonic anhydrase isoform VII acts as a molecular switch in the development of synchronous gamma-frequency firing of hippocampal CA1 pyramidal cells. J Neurosci. 2004; 24; 11: 2699-2707.

21. Viitanen T, Ruusuvuori E, Kaila K, Voipio J. The $\mathrm{K}+-\mathrm{Cl}$ cotransporter KCC2 promotes GABAergic excitation in the mature rat hippocampus. J Physiol. 2010; 588; 9: 15271540 . 